\title{
Aplikasi Amelioran Tanah dan MycoSilvi pada Falcataria sp. dan Ochroma bicolor Rowlee. untuk Reklamasi Lahan Pascatambang Pasir Silika
}

\section{(Application of Soil Ameliorant and MycoSilvi on Falcataria sp. and Ochroma bicolor Rowlee. for Reclamation of Land Post Mining of Silica Sand)}

\author{
Khoryfatul Munawaroh $^{1 \star}$, Sri Wilarso Budi ${ }^{2}$, Prijanto Pamoengkas ${ }^{2}$ \\ (Diterima Februari 2018/Disetujui Maret 2020)
}

\begin{abstract}
ABSTRAK
Kegiatan penambangan terbuka pada tambang pasir menyebabkan degradasi lahan dan kerusakan lingkungan. Kerusakan lahan akibat penambangan tersebut di antaranya adalah kehilangan unsur hara, penurunan $\mathrm{pH}$ tanah, toksisitas tanah karena kelebihan unsur hara mikro ( $\mathrm{Al}, \mathrm{Fe}, \mathrm{Cu}$, dan $\mathrm{Zn}$ ), pemadatan tanah, dan kehilangan vegetasi penutup tanah. Upaya perbaikan tanah perlu dilakukan agar tanah dapat ditanami kembali. Tujuan penelitian ini adalah untuk mengidentifikasi sifat kimia tanah di lahan pascatambang pasir silika dan menganalisis respons pertumbuhan Falcataria sp. dan Ochroma bicolor terhadap kombinasi perlakuan amelioran tanah dan MycoSilvi yang paling optimal. Penelitian ini menggunakan rancangan acak lengkap dengan petak terbagi yang terdiri atas dua faktor, yaitu MycoSilvi dan amelioran tanah. Petak utama adalah MycoSilvi yang terdiri atas dua taraf (MycoSilvi dan tanpa MycoSilvi). Anak petaknya adalah amelioran tanah yang terdiri atas enam taraf (kompos $0 \mathrm{~g}$, kapur $0 \mathrm{~g}$; kompos $0 \mathrm{~g}$, kapur 1,56 g; kompos $0 \mathrm{~g}$, kapur 3,12; kompos $9 \mathrm{~g}$, kapur $0 \mathrm{~g}$; kompos $9 \mathrm{~g}$, kapur 1,56 g; kompos $9 \mathrm{~g}$, kapur 3,12 g). Hasil penelitian menunjukkan bahwa amelioran tanah (kompos $9 \mathrm{~g}$, kapur 3,12 g) dan MycoSilvi adalah perlakuan terbaik dalam meningkatkan pertumbuhan tinggi, diameter, biomassa, dan kolonisasi akar pada Falcataria sp. and $O$. bicolor.
\end{abstract}

Kata kunci: amelioran tanah, MycoSilvi, reklamasi

\section{ABSTRACT}

Open pit mining of silica sand causes some soil degradations and environmental impacts, such as lowering soil $\mathrm{pH}$, lowering soil fertility, soil compaction, and toxicity of micronutrients such as $\mathrm{Al}, \mathrm{Fe}$, and $\mathrm{Zn}$. The aim of this study was to analyze the soil properties of land post mining of silica sand and to analyze the growth response of Falcataria sp. and Ochroma bicolor by combination of soil ameliorant and MycoSilvi. The experimental design was split plot design of two treatment factors, MycoSilvi and soil ameliorant. The main plot is MycoSilvi that consist of two levels (MycoSilvi and without MycoSilvi). The subplot is soil ameliorant that consisted of six levels (compost $0 \mathrm{~g}$, lime $\mathbf{0} \mathrm{g}$; compost $0 \mathrm{~g}$, lime $1.56 \mathrm{~g}$; compost $0 \mathrm{~g}$, lime 3.12; compost $9 \mathrm{~g}$, lime $0 \mathrm{~g}$; compost $9 \mathrm{~g}$, lime $1.56 \mathrm{~g}$; compost $9 \mathrm{~g}$, lime $3.12 \mathrm{~g}$ ). The results showed that the soil ameliorant (lime $3.12 \mathrm{~g}$ and compost $9 \mathrm{~g}$ ) and MycoSilvi was the best treatment to increase height, diameter, biomass, and mycorrhizal colonization of Falcataria sp. and 0 . bicolor.

Keywords: MycoSilvi, reclamation, soil ameliorant

\section{PENDAHULUAN}

Industri penambangan terus berkembang di Indonesia, termasuk penambangan pasir silika. Silika adalah senyawa kimia dengan rumus molekul $\mathrm{SiO}_{2}$ (silikon dioksida) yang dapat diperoleh dari silika mineral, nabati, dan sintesis kristal. Silika mineral adalah senyawa yang banyak ditemukan dalam bahan tambang/galian yang berupa mineral, seperti pasir kuarsa, granit, dan fledsfar yang mengandung kristalkristal silika $\left(\mathrm{SiO}_{2}\right)$ (Bragmann \& Goncalves 2006).

\footnotetext{
1 Sekolah Pascasarjana, Fakultas Kehutanan, Institut Pertanian Bogor, Kampus IPB Darmaga, Bogor16680

2 Departemen Silvikultur, Fakultas Kehutanan, Institut Pertanian Bogor, Kampus IPB Darmaga, Bogor 16680

* Penulis Korespondensi: Email: qory.fm@gmail.com
}

Penambangan pasir silika dilakukan secara terbuka (open pit mining) seperti pada penambangan hasil bumi lainnya. Penambangan terbuka dilakukan dengan cara membersihkan permukaan tanah dari vegetasi (land clearing), pembersihan tanah pucuk (top soil) dan memindahkannya ke lokasi yang telah ditentukan untuk digunakan kembali pada kegiatan reklamasi, penggalian lapisan tanah yang menutupi bahan tambang (overburden), kemudian menggali bahan tambang (Arafat 2015). Adanya rangkaian kegiatan penambangan tersebut akan mengakibatkan lahan terdegradasi karena kehilangan vegetasi penutup tanah dan adanya pembukaan lapisan tanah.

Lahan pascatambang yang sudah terdegradasi tersebut mengalami kerusakan fisik, kimia, dan biologi. Tanah yang sudah mengalami degradasi seperti ini bersifat toxic (beracun), kompak (tanah padat sehingga 
sulit ditembus akar tanaman), unsur hara rendah akibat pencucian tanah dan tidak ada vegetasi pelindung tanah, dan tanah masam $(\mathrm{pH}<5)$. Dampak global lingkungan akibat penambangan adalah penurunan jumlah vegetasi yang mampu mengikat $\mathrm{CO}_{2}$ di udara melalui proses fotosintesis tumbuhan yang mengakibatkan jumlah $\mathrm{CO}_{2}$ di udara meningkat, kenaikan suhu udara, erosi tanah, dan kehilangan biodiversitas.

Meninjau besarnya dampak kerusakan lingkungan yang ditimbulkan oleh kegiatan penambangan tersebut maka setiap perusahaan tambang diwajibkan untuk melakukan reklamasi daerah operasinya untuk dapat ditanami kembali. Hal ini sesuai dengan Peraturan Menteri Energi dan Sumber Daya Mineral Republik Indonesia No 07 Tahun 2014 tentang Pelaksanaan reklamasi dan pascatambang pada kegiatan usaha pertambangan mineral dan batubara.

Upaya perbaikan tanah perlu dilakukan agar tanah dapat ditanami kembali, seperti dengan cara menambahkan amelioran tanah dan pupuk hayati yang mengandung organisme hidup yang mampu memperbaiki kesuburan tanah. Menurut Adimihardja \& Sutono (2005), amelioran atau pembenah tanah merupakan bahan yang ditambahkan ke dalam tanah untuk memerbaiki lingkungan akar bagi pertumbuhan tanaman. Pemberian amelioran dimaksudkan sebagai sumber hara, mengurangi kemasaman tanah, dan sebagai sumber pengikat atau penjerap kation-kation yang tercuci akibat aliran air serta meningkatkan kesuburan tanah di lahan kering. Amelioran dapat berupa arang sekam, kompos, kapur, pupuk, atau zeolit. Penambahan amelioran ini dapat meningkatkan kualitas tanah sehingga dapat ditanami kembali (Balitbang Pertanian 2011).

Pupuk hayati yang mengandung mikrob mampu memperbaiki kualitas tumbuh tanaman. Salah satu pupuk hayati yang dapat digunakan adalah FMA (Fungi Mikoriza Arbuskula). FMA adalah asosiasi antara fungi dengan akar tanaman tingkat tinggi. Interaksi ini akan menghasilkan hubungan timbal balik, yaitu fungi memperoleh sumber makanan dari eksudat akar tanaman dan tanaman akan mendapat unsur hara dan air yang tidak dapat dijangkau oleh akar tanaman karena ukuran hifa pada FMA jauh lebih kecil dibandingkan dengan rambut akar (Sullia 1991). FMA yang bersimbiosis dengan bakteri mampu meningkatkan kualitas tumbuh tanaman lebih baik lagi, seperti MycoSilvi. MycoSilvi merupakan pupuk hayati berupa inokulum FMA yang diperkaya dengan Mychorrizal Helper Bacteria (MHBs). MHBs juga mampu meningkatkan panjang hifa eksternal dan resistensi terhadap patogen (Budi \& May 2012).

Jenis tanaman yang biasa digunakan dalam reklamasi lahan pascatambang adalah jenis yang cepat tumbuh, jenis lokal, memiliki kemampuan adaptabilitas yang tinggi, dan memiliki nilai ekonomi, seperti Falcataria sp. (sengon merah) dan $O$. bicolor (balsa). Tujuan penelitian ini adalah untuk mengidentifikasi sifat kimia tanah di lahan pascatambang pasir silika dan menganalisis respons pertumbuhan Falcataria sp. dan $O$. bicolor terhadap kombinasi perlakuan amelioran tanah dan MycoSilvi yang paling optimal.

\section{METODE PENELITIAN}

\section{Waktu dan Tempat}

Penelitian dilaksanakan selama 6 bulan (Desember 2016-Mei 2017). Penelitian ini dilaksanakan di rumah kaca Departemen Silvikultur dan Laboratorium Teknologi Mikoriza dan Kualitas Benih, Departemen Silvikultur, Fakultas Kehutanan, Institut Pertanian Bogor. Contoh tanah yang digunakan diambil dari lahan pascatambang pasir silika yang berlokasi di Desa Sekarwangi, Kecamatan Cibadak, Kabupaten Sukabumi dan dianalisis di Laboratorium Departemen IImu Tanah, Fakultas Pertanian, Institut Pertanian Bogor.

\section{Bahan dan Alat}

Bahan yang digunakan dalam penelitian ini adalah aquades, larutan $\mathrm{KOH} 10 \%, \mathrm{HCl} 0,1 \mathrm{M}$, larutan destaining, $\mathrm{HCl} 0,1 \mathrm{M}$, larutan glukosa $60 \%$, larutan pewarna biru anilina (trypan blue), polyvynil alcohol lactogliserol (PVLG), melzer'sreagent, benih Falcataria sp., benih $O$. bicolor, zeolit, kompos, tanah pascatambang silika, kapur dolomit, dan fungisida untuk pemeliharaan selama penyemaian. Alat yang digunakan dalam penelitian ini adalah autoclave, oven, centrifuge, micro pipet, preparat glass set, saringan mikron (500 $\mu \mathrm{m}, 125 \mu \mathrm{m}, 63 \mu \mathrm{m})$, labu erlenmayer, gelas takar, timbangan analitik, gunting, plastic crap, kertas label, kamera, cawan petri, polybag, sprayer, dissecting microscope, compound microscope, penggaris, dan caliper digital.

\section{Pengambilan Contoh Tanah Pascatambang Pasir Silika}

Contoh tanah yang digunakan berasal dari lahan pascatambang pasir silika di Desa Sekarwangi, Kecamatan Cibadak, Kabupaten Sukabumi. Contoh tanah untuk pengamatan sifat kimia merupakan contoh komposit yang diambil dari beberapa titik dan diambil pada kedalaman $20 \mathrm{~cm}$ dan dianalisis di Laboratorium Ilmu Tanah, IPB.

\section{Pengamatan Jumlah Spora Inokulum}

MycoSilvi yang digunakan untuk penelitian ini diinokulasikan pada tanaman inang Pueraria javanica dengan media zeolit. Jumlah zeolit yang digunakan dalam pengamatan tersebut adalah $5 \mathrm{~g}$ dan diperoleh rata-rata jumlah spora 27 spora/5 g media zeolit. Menurut Brundrett et al. (1996), inokulan yang digunakan adalah minimum 50 spora/tanaman sehingga jumlah media zeolit yang digunakan dalam penelitian ini adalah sebanyak $10 \mathrm{~g} /$ tanaman. 


\section{Pengecambahan benih Falcataria sp. dan 0 . bicolor}

Benih Falcataria $s p$. dan $O$. bicolor direndam dengan air panas $\left(80^{\circ} \mathrm{C}\right)$ selama 15 menit kemudian direndam dengan air suhu ruangan selama 24 jam kemudian disemai pada media zeolit halus.

\section{Persiapan Media Tanam}

Media yang digunakan disterilisasi terlebih dahulu dengan menggunakan autoclave. Sterilisasi dilakukan dengan cara memasukkan tanah pada plastik yang tahan panas dan dimasukkan ke dalam autoclave dengan suhu $121^{\circ} \mathrm{C}$ selama 1 jam.

\section{Pemberian Perlakuan Media}

Media yang sudah disterilisasi selanjutnya dimasukkan ke dalam polybag ukuran $15 \times 12 \mathrm{~cm}$ dengan bobot media setiap polybag adalah $300 \mathrm{~g}$. Media yang sudah disiapkan dalam polybag, selanjutnya diberi tambahan amelioran tanah yang terdiri atas kapur dan kompos yang dosisnya ditentukan berdasarkan hasil analisis tanah yang diperoleh. Penambahan MycoSilvi diberikan pada saat penyapihan bibit ke polybag.

\section{Penyapihan dan Inokulasi MycoSilvi}

Bibit disapih pada media yang sudah diberikan perlakuan pada setiap polybag. MycoSilvi sebanyak 10 $\mathrm{g}$ diletakkan di dekat akar bibit pada saat penyapihan.

\section{Pengamatan Parameter Pertumbuhan}

Pengamatan parameter pertumbuhan dilakukan pada saat 16 minggu setelah tanam (MST) dengan parameter yang diukur adalah tinggi dan diameter, biomassa tanaman, dan kolonisasi akar. Pengukuran tinggi dilakukan setiap 2 minggu. Kolonisasi mikoriza pada akar ditentukan setelah akar dibersihkan menggunakan $\mathrm{KOH} 10 \%$, direndam $\mathrm{HCL} 0,1 \mathrm{M}$, destaining menggunakan trypan blue, dan direndam dengan menggunakan asam laktat sebagai larutan destaining.

\section{Model Rancangan Penelitian}

Rancangan percobaan dalam penelitian ini menggunakan rancangan acak lengkap (RAL) dengan rancangan petak terbagi atau split plot design yang terdiri atas dua faktor perlakuan, yaitu MycoSilvi dan amelioran tanah. Petak utama adalah MycoSilvi yang terdiri atas 2 taraf, sedangkan anak petaknya adalah amelioran tanah yang terdiri atas 6 taraf. Interaksi dua faktor perlakuan tersebut menghasilkan 12 kombinasi perlakuan dengan 5 ulangan sehingga terdapat 60 unit percobaan untuk setiap jenis.

$$
\begin{array}{ll}
\text { Faktor } 1 & =\text { MycoSilvi } \\
\text { M0 } & =\text { Tanpa MycoSilvi } \\
\text { M1 } & =\text { Dengan MycoSilvi }
\end{array}
$$

Faktor 2 = Amelioran tanah A0 $=$ Kompos $0 \mathrm{~g}$, kapur $0 \mathrm{~g}$

$$
\begin{array}{ll}
\text { A1 } & =\text { Kompos } 0 \mathrm{~g}, \text { kapur } 1,56 \mathrm{~g} \\
\text { A2 } & =\text { Kompos } 0 \mathrm{~g}, \text { kapur } 3,12 \mathrm{~g} \\
\text { A3 } & =\text { Kompos } 9 \mathrm{~g} \text {, kapur } 0 \mathrm{~g} \\
\text { A4 } & =\text { Kompos } 9 \mathrm{~g} \text {, kapur } 1,56 \mathrm{~g} \\
\text { A5 } & =\text { Kompos } 9 \mathrm{~g} \text {, kapur } 3,12 \mathrm{~g}
\end{array}
$$

\section{Analisis Data}

Analisis sidik ragam (ANOVA) pada tingkat kepercayaan $95 \%$ sesuai dengan model Rancangan Petak Terbagi (RPT) (Mattjik \& Sumertajaya 2013). Jika perlakuan berpengaruh nyata maka dilanjutkan dengan uji lanjut Duncan. Pengolahan data statistik menggunakan bantuan software SPSS. Model linear aditif dalam penelitian ini adalah sebagai berikut (Mattjik \& Sumertajaya 2013):

$$
Y_{i j}=\mu+K_{l}+A_{i}+Y_{i l}+B_{j}+(A B)_{i j}+\varepsilon_{i j l}
$$

\section{HASIL DAN PEMBAHASAN}

\section{Karakteristik Media}

Hasil analisis sifat kimia tanah pascatambang pasir silika menunjukkan bahwa lahan tersebut adalah lahan marjinal dengan beberapa faktor pembatas tanaman, seperti $\mathrm{pH}$ sangat masam, tanah yang terlalu padat, $\mathrm{Al}$ yang tinggi, dan $\mathrm{P}$-tersedia yang sangat rendah. Data tersebut tersaji dalam Tabel 1.

Tanah yang sangat masam pada media penelitian ini dinaikkan $\mathrm{pH}$ nya dengan cara menambahkan kapur. Kapur dengan dosis 3,12 g/polybag mampu menaikkan $\mathrm{pH}$ menjadi netral $(6,23-7,17)$ dan menurunkan Al hingga menjadi tidak terukur, serta meningkatkan unsur $P$. Perubahan terbaik pada sifat kimia tanah terdapat pada perlakuan penambahan kapur $3,12 \mathrm{~g}$ dan kompos $9 \mathrm{~g}$, sedangkan tanah yang hanya diberi perlakuan MycoSilvi saja tidak menunjukkan perubahan yang signifikan pada tanah sebelum penelitian. Perubahan signifikan pada perlakuan ditunjukkan pada parameter unsur Al, di mana $\mathrm{Al}$ akan menurun seiring dengan peningkatan $\mathrm{pH}$ tanah. Kapur yang bermuatan negatif $\left(\mathrm{CaMg}\left(\mathrm{CO}_{3}\right)^{2-}\right.$ akan mengikat Al yang bermuatan positif $\left(\mathrm{Al}^{3+}\right)$.

\section{Pertumbuhan Tinggi dan Diameter Falcataria sp. dan O. bicolor}

Pertumbuhan tinggi, diameter, dan biomassa merupakan parameter yang dapat digunakan untuk mengetahui kualitas semai. Persen kolonisasi akar merupakan parameter untuk mengetahui kesesuaian tanaman inang dengan MycoSilvi. Perbaikan tanah yang dilakukan pada penelitian ini menunjukkan hasil yang signifikan. Hal ini ditunjukkan oleh parameter pertumbuhan tinggi yang diamati setelah pengamatan selama 16 minggu setelah tanam (MST) (Tabel 2).

Hasil yang paling baik pada parameter tinggi terdapat pada perlakuan penambahan MycoSilvi, kompos $9 \mathrm{~g}$ dan kapur $3,12 \mathrm{~g}$ (M1A5), baik pada jenis Falcataria sp. maupun $O$. Bicolor, seperti tersaji dalam Gambar 1.

Grafik pertumbuhan tinggi pada $O$. bicolor mengalami pertumbuhan setiap minggunya, kecuali pada 
Tabel 1 Hasil analisis sifat kimia tanah pascatambang pasir silika sebelum penelitian

\begin{tabular}{lrll}
\hline \multicolumn{1}{c}{ Parameter } & Nilai & Satuan & Kriteria* $^{*}$ \\
\hline $\mathrm{pH} \mathrm{H}_{2} \mathrm{O}$ & 2,22 & & Sangat masam \\
$\mathrm{C}-$ org & 2,33 & $(\%)$ & Sedang \\
$\mathrm{N}-$ Total & 0,11 & $(\%)$ & Rendah \\
$\mathrm{P}$ tersedia & 1,83 & $(\mathrm{ppm})$ & Sangat rendah \\
$\mathrm{P}$ total & 118,43 & $(\mathrm{ppm})$ & Sangat tinggi \\
$\mathrm{Ca}$ & 4,83 & $\left(\mathrm{cmol}^{+} / \mathrm{kg}\right)$ & Rendah \\
$\mathrm{Mg}$ & 4,56 & $\left(\mathrm{cmol}^{+} / \mathrm{kg}\right)$ & Tinggi \\
$\mathrm{K}$ & 0,08 & $\left(\mathrm{cmol}^{+} / \mathrm{kg}\right)$ & Sangat rendah \\
$\mathrm{Na}$ & 0,05 & $\left(\mathrm{cmol}^{+} / \mathrm{kg}\right)$ & Sangat rendah \\
$\mathrm{KTK}$ & 8,79 & $(\%)$ & Rendah \\
$\mathrm{KB}$ & 108,37 & $(\mathrm{cmol}+\mathrm{kg})$ & Sangat tinggi \\
$\mathrm{Al}$ & 11,41 & $(\mathrm{cmol}+/ \mathrm{kg})$ & Tinggi \\
$\mathrm{H}$ & 8,92 & $(\mathrm{ppm})$ & Sangat tinggi \\
$\mathrm{Fe}$ & 409,75 & $(\mathrm{ppm})$ & Rendah \\
$\mathrm{Cu}$ & 2,76 & $(\mathrm{ppm})$ & Rendah \\
$\mathrm{Zn}$ & 18,43 & $(\mathrm{ppm})$ & Sangat tinggi \\
$\mathrm{Mn}$ & 41,67 & & Lempung berdebu \\
$\mathrm{Tekstur}$ & & & \\
$\quad$ Pasir & 8,50 & & \\
Debu & 62,73 & & \\
\hline
\end{tabular}

Tabel 2 Pertumbuhan tinggi tanaman Falcataria sp. dan O. Bicolor 16 minggu setelah tanam (MST)

\begin{tabular}{|c|c|c|}
\hline \multirow{2}{*}{ Perlakuan } & \multicolumn{2}{|c|}{ Pertumbuhan tinggi semai $(\mathrm{cm})$} \\
\hline & Falcataria sp. & O. bicolor \\
\hline Kompos 0 g, kapur 0 g, tanpa MycoSilvi (Kontrol) & $0,35^{d}$ & $0,40^{g}$ \\
\hline Kompos $0 \mathrm{~g}$, kapur 1,56 g, tanpa MycoSilvi (M0A1) & $0,95^{\mathrm{cd}}$ & $1,40^{f}$ \\
\hline Kompos $0 \mathrm{~g}$, kapur 3,12 g, tanpa MycoSilvi (M0A2) & $1,62^{\mathrm{bcd}}$ & $2,57^{e}$ \\
\hline Kompos $9 \mathrm{~g}$, kapur $0 \mathrm{~g}$, tanpa MycoSilvi (MOA3) & $0,57^{d}$ & $1,00^{f g}$ \\
\hline Kompos $9 \mathrm{~g}$, kapur $1,56 \mathrm{~g}$, tanpa MycoSilvi (MOA4) & $2,43^{\text {bcd }}$ & $4,33^{\mathrm{cd}}$ \\
\hline Kompos $9 \mathrm{~g}$, kapur 3,12 g, tanpa MycoSilvi (M0A5) & $2,82^{\mathrm{abc}}$ & $4,97^{b c}$ \\
\hline Kompos $0 \mathrm{~g}$, kapur $0 \mathrm{~g}$, dengan MycoSilvi (M1A0) & $0,27^{d}$ & 0,039 \\
\hline Kompos $0 \mathrm{~g}$, kapur 1,56 g, dengan MycoSilvi (M1A1) & $1,37^{\mathrm{cd}}$ & $2,40^{e}$ \\
\hline Kompos $0 \mathrm{~g}$, kapur 3,12 g, dengan MycoSilvi (M1A2) & $2,50^{\text {bcd }}$ & $3,50^{d}$ \\
\hline Kompos $9 \mathrm{~g}$, kapur $0 \mathrm{~g}$, dengan MycoSilvi (M1A3) & $0,53^{d}$ & $0,50^{\mathrm{fg}}$ \\
\hline Kompos $9 \mathrm{~g}$, kapur $1,56 \mathrm{~g}$, dengan MycoSilvi (M1A3) & $3,72^{\mathrm{ab}}$ & $5,80^{\mathrm{ab}}$ \\
\hline Kompos $9 \mathrm{~g}$, kapur $3,12 \mathrm{~g}$, dengan MycoSilvi (M1 A3) & $4,77^{a}$ & $6,00^{\mathrm{a}}$ \\
\hline
\end{tabular}

Keterangan: Angka pada kolom yang sama diikuti huruf yang sama tidak berbeda nyata berdasarkan uji-F pada selang kepercayaan $95 \%$.

perlakuan kapur $0 \mathrm{~g}$, kompos $0 \mathrm{~g}$, tanpa MycoSilvi (MOA0) dan kapur $0 \mathrm{~g}$, kompos $0 \mathrm{~g}$, dengan MycoSilvi (M1A0). Hal ini ditunjukkan pada grafik yang datar yang menunjukkan bahwa pada perlakuan tersebut tanaman tidak dapat bertahan hidup tanpa penambahan kompos dan kapur. Media dengan $\mathrm{pH}$ yang sangat masam, Al tinggi, dan tanah yang terlalu padat tidak mendukung $O$. bicolor untuk hidup, meskipun sudah ditambahkan MycoSilvi. Sementara itu, pada tanaman Falcataria sp. pertumbuhan tinggi terus meningkat hanya pada perlakuan dengan penambahan MycoSilvi, kompos $0 \mathrm{~g}$, dan kapur 3,12 g (M1A2), penambahan MycoSilvi, kompos $9 \mathrm{~g}$, dan kapur $1,56 \mathrm{~g}$ (M1A4), dan penambahan MycoSilvi, kompos $9 \mathrm{~g}$, dan kapur 3,12 g (M1A5). Hal ini menunjukkan bahwa tanaman Falcataria sp. tidak dapat tumbuh pada media penelitian jika tidak ditambahkan kapur dan MycoSilvi. Kapur pada amelioran tanah yang digunakan memberikan respons yang lebih baik jika dibandingkan dengan penambahan kompos saja, tetapi penambahan kompos dan kapur secara bersamaan membe- rikan respons terbaik jika dibandingkan dengan pemberian dengan kompos saja atau kapur saja. Hal ini disebabkan karena kapur mampu meningkatkan $\mathrm{pH}$ tanah, sedangkan kompos selain mampu meningkatkan kesuburan tanah juga mampu memperbaiki permeabilitas tanah, terutama pada media yang komposisi debu dan liat $>70 \%$, seperti pada media penelitian.

Berdasarkan hasil penelitian Budi \& May (2013), MycoSilvi yang diujikan pada tanaman Acacia decurens dengan media tanah marginal ultisol menunjukkan peningkatan kemampuan fotosintesis dan pertumbuhan tinggi tanaman hingga $100 \%$. Pengujian MycoSilvi juga dilakukan di lapangan pada tanah latosol. Kemampuan hidup tanaman yang diberikan MycoSilvi pada saat musim kemarau panjang adalah sebesar $60 \%$, sementara tanaman kontrol sudah tidak ada yang hidup.

O. bicolor tidak mampu bertahan hidup pada media penelitian tanpa penambahan kapur. Media dengan penambahan kompos $9 \mathrm{~g}$ tanpa disertai dengan penambahan kompos masih memungkinkan $\mathrm{O}$. bicolor 

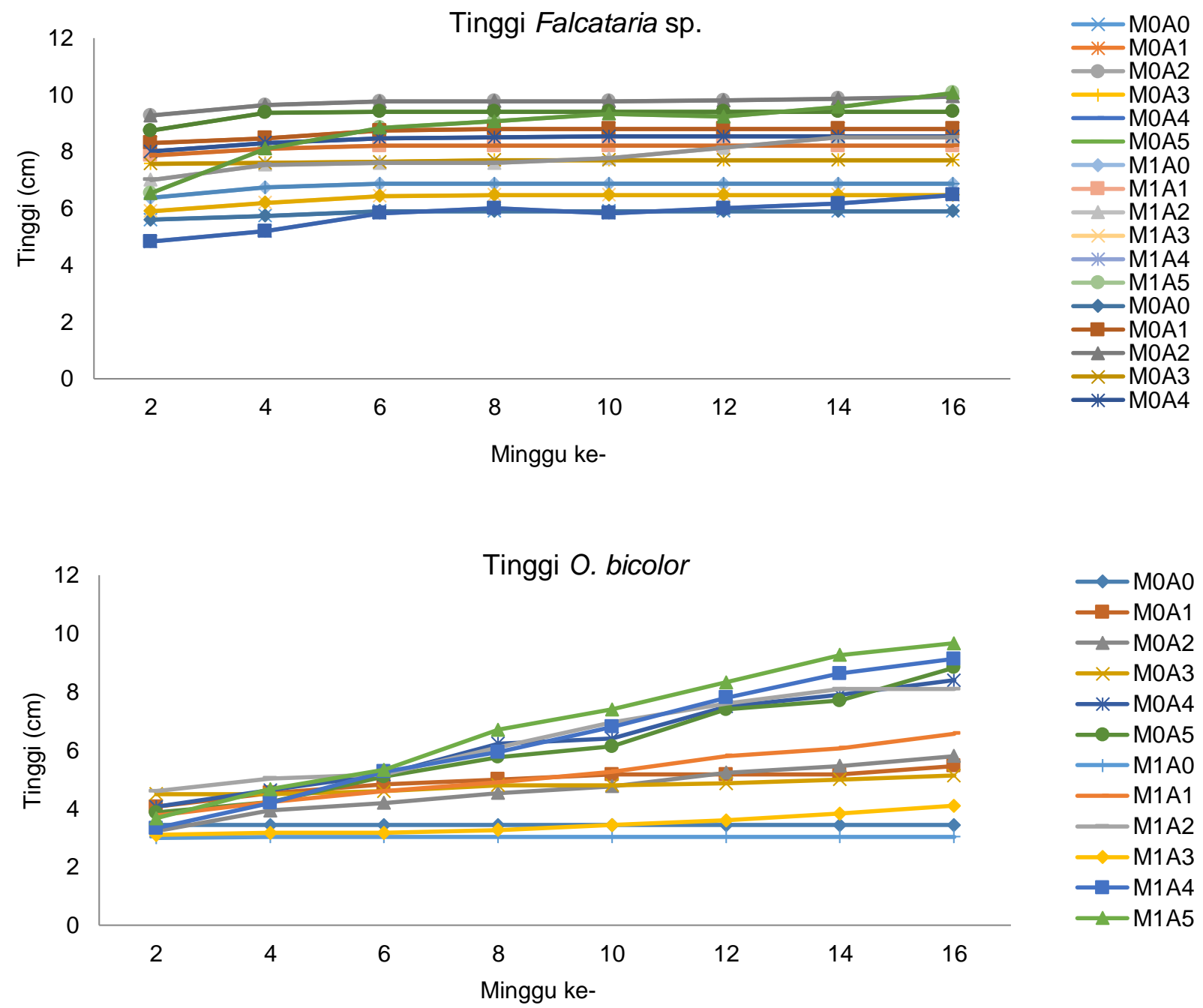

Gambar 1 Grafik pertumbuhan tinggi tanaman Falcataria sp. dan O. bicolor.

untuk hidup dengan nilai persentase hidup $20 \%$ dan memiliki pertumbuhan yang terhambat. Berdasarkan hasil penelitian Istiqomah (2017), tanaman O. bicolor dapat tumbuh pada kondisi tanah yang kurang subur, bahkan tanaman ini dapat mengakumulasikan logam berat $\mathrm{Pb}$ lebih dari 1.000 ppm pada saat bersimbiosis dengan FMA pada lahan podsolik merah kuning. Akan tetapi, tanpa simbiosis dengan FMA dan tanpa perbaikan media, tanaman ini memiliki persentase hidup yang kecil dengan pertumbuhan yang terhambat sehingga $O$. bicolor bukan merupakan tanaman hiperakumulator, meskipun dapat menambat $\mathrm{Pb}$ hingga 1.000 ppm. Pertumbuhan diameter memiliki pola respons pertumbuhan yang serupa seperti pada pertumbuhan tinggi (Tabel 3).

Respons terbaik pertumbuhan diameter $O$. bicolor terdapat pada perlakuan M1A4, tetapi perlakuan M1A4 tidak berbeda nyata dari M1A5. Pertumbuhan diameter Falcataria sp. terus meningkat pada perlakuan M1A5, M1A4, dan M1A2, sedangkan pertumbuhan pada perlakuan yang lain tidak mengalami pertumbuhan hingga akhir pengamatan karena Falcataria sp. tidak mampu bertahan hidup hingga akhir pengamatan. Berbeda dari Falcataria sp., tanaman $O$. bicolor mengalami peningkatan pertumbuhan hampir pada setiap perlakuan, kecuali pada perlakuan MOAO dan M1A0. Hal ini menunjukkan bahwa $O$. bicolor tidak dapat bertahan hidup pada media penelitian tanpa penambahan amelioran tanah, meskipun dengan penambahan MycoSilvi. Akan tetapi, penambahan MycoSilvi memberikan respons yang lebih baik jika dibandingkan dengan perlakuan tanpa MycoSilvi pada perlakuan dengan taraf amelioran tanah yang sama seperti tersaji pada Gambar 2.

Kapur mampu meningkatkan $\mathrm{pH}$ tanah yang mendukung pertumbuhan tanaman dan meningkatkan pertumbuhan diameternya. Kapur 1,56 g dan MycoSilvi (M1A1) menghasilkan pertumbuhan yang lebih baik dibandingkan dengan tanpa MycoSilvi (MOA1). Pertumbuhan diameter akan lebih meningkat pada saat kapur 1,56 g dan MycoSilvi ditambahkan kompos $9 \mathrm{~g}$ (M1A4). Hal ini menunjukkan bahwa MycoSilvi akan mengoptimalkan pertumbuhan diameter tanaman Falcataria sp. dan O. bicolor pada saat kondisi tanah 
Tabel 3 Pertumbuhan diameter tanaman Falcataria sp. dan O. bicolor 16 minggu setelah tanam (MST)

\begin{tabular}{|c|c|c|}
\hline \multirow{2}{*}{ Perlakuan } & \multicolumn{2}{|c|}{ Pertumbuhan diameter semai $(\mathrm{mm})$} \\
\hline & Falcataria sp. & O. bicolor \\
\hline Kompos $0 \mathrm{~g}$, kapur $0 \mathrm{~g}$, tanpa MycoSilvi (Kontrol) & $0,07^{c}$ & $0,00^{e}$ \\
\hline Kompos $0 \mathrm{~g}$, kapur $1,56 \mathrm{~g}$, tanpa MycoSilvi (MOA1) & $0,12^{\mathrm{c}}$ & $0,93^{d}$ \\
\hline Kompos $0 \mathrm{~g}$, kapur 3,12 g, tanpa MycoSilvi (M0A2) & $0,39 \mathrm{bc}$ & $1,09 d$ \\
\hline Kompos $9 \mathrm{~g}$, kapur $0 \mathrm{~g}$, tanpa MycoSilvi (MOA3) & $0,12^{c}$ & 0,46 de \\
\hline Kompos $9 \mathrm{~g}$, kapur 1,56 g, tanpa MycoSilvi (M0A4) & $0,41^{b c}$ & $2,93^{\mathrm{ab}}$ \\
\hline Kompos $9 \mathrm{~g}$, kapur 3,12 g, tanpa MycoSilvi (M0A5) & $0,56 \mathrm{bc}$ & $2,28^{b c}$ \\
\hline Kompos $0 \mathrm{~g}$, kapur $0 \mathrm{~g}$, dengan MycoSilvi (M1A0) & $0,06^{c}$ & $0,07^{e}$ \\
\hline Kompos $0 \mathrm{~g}$, kapur 1,56 g, dengan MycoSilvi (M1A1) & $0,18^{\mathrm{bc}}$ & $1,85^{c}$ \\
\hline Kompos $0 \mathrm{~g}$, kapur 3,12 g, dengan MycoSilvi (M1A2) & $0,70^{\mathrm{ab}}$ & $1,99^{c}$ \\
\hline Kompos $9 \mathrm{~g}$, kapur $0 \mathrm{~g}$, dengan MycoSilvi (M1A3) & $0,09^{c}$ & $0,63^{\text {de }}$ \\
\hline Kompos $9 \mathrm{~g}$, kapur 1,56 g, dengan MycoSilvi (M1A3) & $0,56^{\mathrm{bc}}$ & $3,41^{\mathrm{a}}$ \\
\hline Kompos $9 \mathrm{~g}$, kapur 3,12 g, dengan MycoSilvi (M1A3) & $1,14^{\mathrm{a}}$ & $3,40^{\mathrm{a}}$ \\
\hline
\end{tabular}

Keterangan: Angka pada kolom yang sama diikuti huruf yang sama tidak berbeda nyata berdasarkan uji-F pada selang kepercayaan $95 \%$.
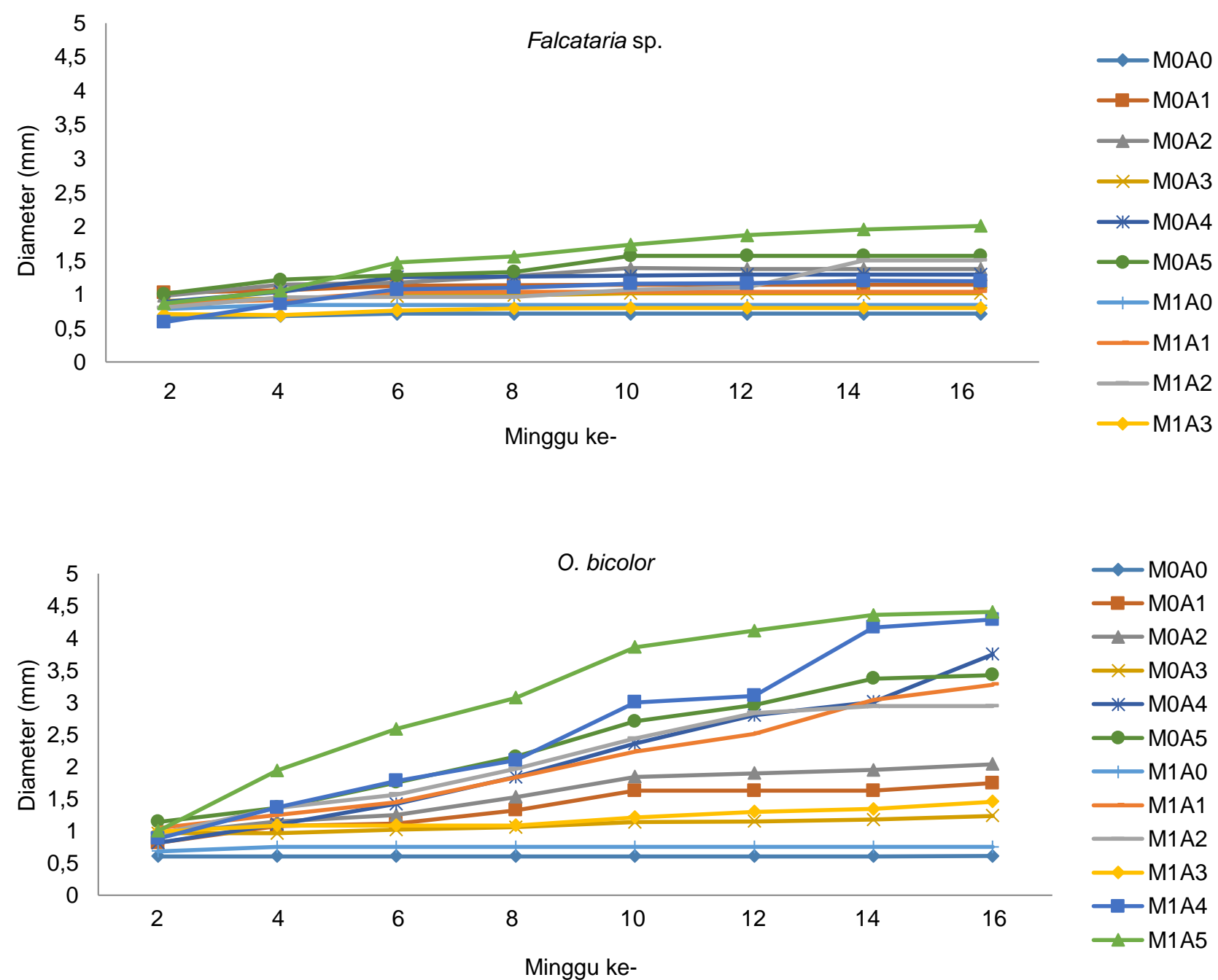

Gambar 2 Grafik pertumbuhan diameter tanaman Falcataria sp. dan O. Bicolor.

memungkinkan bagi tanaman untuk hidup. Hal ini seperti hasil penelitian Jayani (2018) yang menunjukkan bahwa MycoSilvi mampu mengoptimalkan pertumbuhan diameter tanaman $F$. moluccana, $S$. saman, dan $C$. siamea pada kondisi tanah yang sama.

\section{Persentase Kolonisasi FMA}

Kolonisasi akar diukur berdasarkan bidang pandang yang terinfeksi FMA dibandingkan dengan total bidang pandang. Kolonisasi akar dapat ditunjukkan dengan adanya vesikula, arbuskula, hifa, dan spora. 
Hasil persen kolonisasi akar kemudian diklasifikasikan berdasarkan kriteria Rajapakse \& Miller (1992), yaitu kurang dari 5\% sangat rendah, $6-5 \%$ rendah, 26-50\% sedang, $51-75 \%$ tinggi, dan di atas $75 \%$ sangat tinggi dan diperoleh hasil seperti pada Tabel 4 .

Kolonisasi akar meningkat sebanding dengan peningkatan dosis kapur yang diberikan. Hal ini menunjukkan bahwa FMA pada MycoSilvi yang digunakan lebih efektif pada $\mathrm{pH}$ mendekati netral atau netral. Pada saat $\mathrm{pH}$ tanah sudah tidak masam dan mendukung tanaman untuk tumbuh maka MycoSilvi akan berperan meningkatkan pertumbuhan tanaman dengan cara memperoleh air dan unsur hara melalui hifa eksternal. Kriteria kolonisasi akar yang sangat tinggi pada jenis $O$. bicolor menunjukkan bahwa $O$. bicolor memilki kemampuan yang lebih baik untuk bersimbiosis dengan FMA. Selain itu, kriteria sedang hingga sangat tinggi pada beberapa perlakuan disebabkan oleh media penelitian yang memiliki unsur $\mathrm{N}$ rendah dan $\mathrm{P}$-tersedia yang sangat rendah. Menurut Farzanah et al. (2011), semakin besar kandungan $\mathrm{N}$ dan P-tersedia maka semakin kecil persentase kolonisasi mikoriza. Kolonisasi akar O. bicolor dan Falcataria sp. dapat dilihat pada Gambar 3.

Kolonisasi yang dijumpai pada perlakuan kapur $0 \mathrm{~g}$ (M1A0 dan M1A3) hanya berupa hifa. Pada perlakuan ini, tanaman tidak mampu bertahan hidup karena $\mathrm{pH}$

yang terlalu masam dan Al yang terlalu tinggi serta tidak tersedianya hara yang cukup bagi tanaman. Oleh karena itu, tanaman akan mati meskipun sudah diinfeksi oleh hifa FMA dan tidak dapat bertahan pada tahap fungsi simbiotik. Fungsi simbiotik adalah kondisi pada saat mantel hifa telah berkembang dan hartig net b erkembang sempurna. Pada saat fungsi simbiotik sudah terjadi maka kolonisasi akar oleh FMA juga dapat terjadi.

\section{KESIMPULAN}

Hasil penelitian menunjukkan bahwa pada inokulasi antara amelioran tanah dan MycoSilvi menunjukkan pengaruh yang nyata pada setiap perlakuan. Penambahan kapur dan kompos menunjukkan pengaruh yang nyata pada setiap dosis yang digunakan. Secara umum hasil yang paling baik terdapat pada perlakuan M1A5 (kompos $9 \mathrm{~g}$, kapur 3,12 g, penambahan MycoSilvi) pada pertumbuhan parameter tinggi, diameter, biomassa, dan kolonisasi akar, terutama pada jenis $O$. bicolor. O. bicolor lebih dapat bertahan hidup pada tanah marjinal dibandingkan dengan Falcataria sp. Fisiologi tanaman ini membuatnya lebih mampu bertahan jika dibandingkan dengan Falcataria sp.

Tabel 4 Kolonisasi akar tanaman pada umur 16 minggu setelah tanam (MST)

\begin{tabular}{lrr}
\hline \multicolumn{1}{c}{ Perlakuan } & \multicolumn{2}{c}{ Kolonisasi fungi mikoriza arbuskula (FMA) } \\
\cline { 2 - 3 } & Falcataria sp. (\%) & O. bicolor (\%) \\
\hline Kompos 0 g, kapur 0 g, tanpa MycoSilvi (M0A0) & $0,00^{\mathrm{c}}$ & $0,00^{\mathrm{c}}$ \\
Kompos 0 g, kapur 0 g, dengan MycoSilvi (M1A0) & $30,00^{\mathrm{b}}$ & $40,00^{\mathrm{b}}$ \\
Kompos 0 g, kapur 1,56 g, dengan MycoSilvi (M1A1) & $30,00^{\mathrm{b}}$ & $86,67^{\mathrm{a}}$ \\
Kompos 0 g, kapur 3,12 g, dengan MycoSilvi (M1A2) & $96,67^{\mathrm{a}}$ & $100,00^{\mathrm{a}}$ \\
Kompos 9 g, kapur 0 g, dengan MycoSilvi (M1A3) & $26,67^{\mathrm{b}}$ & $90,00^{\mathrm{a}}$ \\
Kompos 9 g, kapur 1,56 g, dengan MycoSilvi (M1A3) & $60,00^{\mathrm{ab}}$ & $96,67^{\mathrm{a}}$ \\
Kompos 9 g, kapur 3,12 g, dengan MycoSilvi (M1A3) & $93,33^{\mathrm{a}}$ & $100,00^{\mathrm{a}}$ \\
\hline
\end{tabular}

Sumber: Rajapakse \& Miller (1992).

Keterangan: Angka pada kolom yang sama diikuti huruf yang sama tidak berbeda nyata berdasarkan uji-F pada selang kepercayaan $95 \%$.

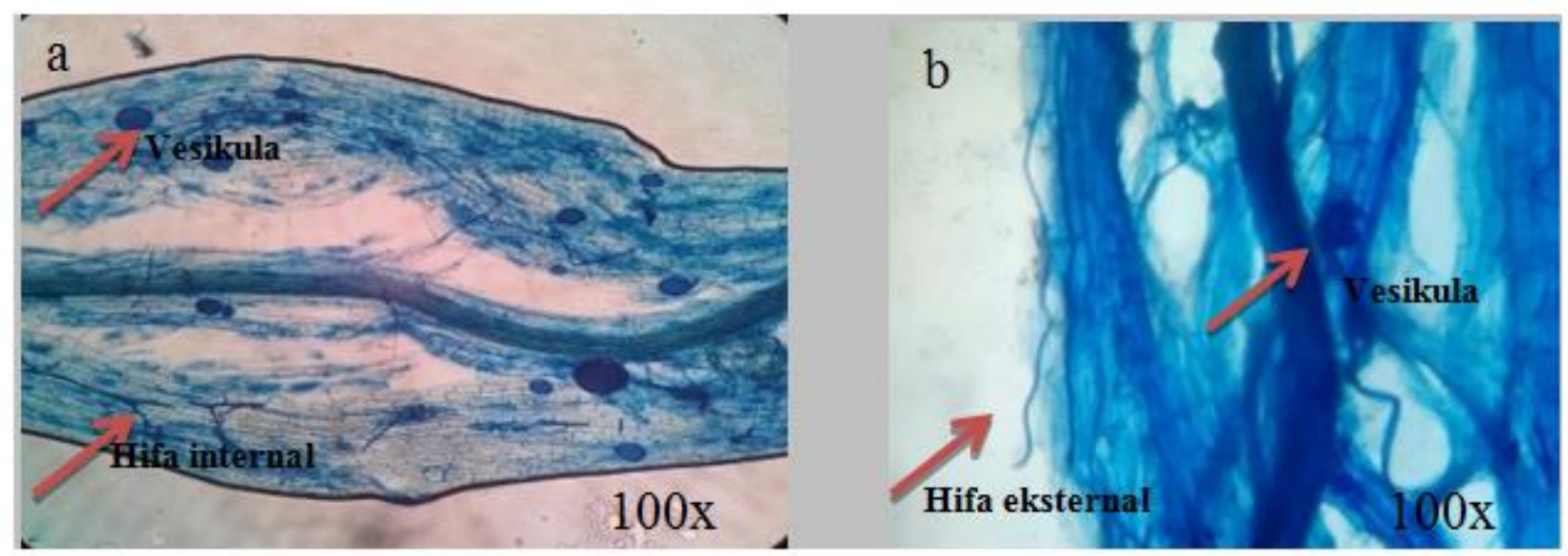

Gambar 3 Kolonisasi akar pada semai a) O. bicolor dan b) Falcataria sp. 


\section{DAFTAR PUSTAKA}

Adimihardja A, Sutono S. $2005 . \quad$ Teknologi pengendalian erosi lahan berlerang. Dalam: Marham (eds): Prosiding Teknologi Pengelolaan Lahan Kering Menuju Petanian Produktif dan Ramah Lingkungan. Pusat Penelitian dan Pengembangan Tanah dan Agroklimat. Bogor (ID): 4-5 Juni 2005.

Arafat IN. 2015. Pertumbuhan Desmodium heterophyllum (Willd.) Dc. sebagai Tanaman Penutup Tanah di Lahan Bekas Tambang pasir silika. [skripsi]. Bogor (ID): Institut Pertanian Bogor.

[Balitbang Pertanian] Badan Penelitian dan Pengembangan Pertanian. 2011. Ameliorasi tanah gambut meningkatkan produksi padi dan menekan emisi gas rumah kaca. Agroinovasi. No 3400.

Bragmann CP, Goncalves MRF. 2006. Thermal Insulators Made With Rice Husk Ashes: Production and Correlation Between Properties and Microstructure. Brasil (BR): Federal university of Rio Grande do Sul.

Brundrett M, Bougher N, Dell B, Grove T, Malajczuk N. 1996. Working with mychorrizas in forestry and agriculture. Canberra (AU): Australian Centre for International Agricultural Research.

Budi SW, May NL. 2013. Bacteria from arbuscular mycorrhizal fungi spores Gigaspora sp. and Glomus sp.: their antagonistic effects towards soilborne fungal pathogens and growth stimulation of Gigaspora sp. in vitro. Journal of Biotropia. 20(1): 38-49.

Farzanah M, Vierheilig H, Lossl A, Kaul HP. 2011. Arbuscula mychorryza enhances nutrient uptake in chickpea. Plant Soil Environment. 57(10): 465-470. https://doi.org/10.17221/133/2011-PSE
Hardjowigeno S. 2003. Ilmu Tanah. Jakarta (ID). Akademika Pressindo.

Havlin JL, Beaton JD, Tisdale SL, Nelson WL. 1999. Soil Fertility and Fertilizers (An Introduction to Nutrient Management). New Jersey (USA): Prentice Hall.

Istiqomah FN. 2017. Peran Fungi Mikoriza Arbuskula dan Asam Humat Terhadap Pertumbuhan Balsa (Ochroma bicolor Rowlee.) pada Tanah Terkontaminasi Timbal. [tesis]. Bogor (ID): Institut Pertanian Bogor

Jayani FM. 2018. Respons Pertumbuhan Tanaman Kehutanan Terhadap Penambahan Amelioran Tanah dan MycoSilvi pada Media Tanah Pascatambang Pasir Silika. [tesis]. Bogor (ID): Institut Pertanian Bogor.

[Kementerian ESDM] Kementerian Energi dan Sumber Daya Mineral. 2014. Peraturan Menteri Energi dan Sumber Daya Mineral Republik Indonesia No 07 Tahun 2014 tentang Pelaksanaan reklamasi dan pascatambang pada kegiatan usaha pertambangan mineral dan batubara. Jakarta (ID): Kementerian ESDM.

Mattjik AA, Sumertajaya IM. 2013. Perancangan Percobaan dengan Aplikasi SAS dan Minitab. Bogor (ID): IPB Press.

Rajapakse S, Miller Jr JC. 1992. Methods for studying vesicular-arbuscular mycorrhizal root colonozation and related root physical properties. Methods Microbiol. 24: 302-306.

Sandi C, Flores EM. 2004. Ochroma pyramidale (Cav. Ex. Lam.) Urb. Journal of Species Descriptions. 586-588. 